INTERNATIONAL JOURNAL OF MULTidisciplinARY RESEARCH AND ANALYSis

ISSN(print): 2643-9840, ISSN(online): 2643-9875

Volume 05 Issue 03 March 2022

DOI: 10.47191/ijmra/v5-i3-04, Impact Factor: 6.072

Page No. 606-615

\title{
Study of the Correlation between Arm Muscle Power, Arm Length, Hand-Eye Coordination, and Concentration on Gate-In Results in Woodball
}

Nisa 'Urizka Fayogi ${ }^{1}$, Endang Rini Sukamti ${ }^{2}$, Amri Hartanto ${ }^{3}$, Betrix Teofa Perkasa Wibafiet Billy Yachsie ${ }^{4}$, Andrian Rahman Ayudi ${ }^{5}$, Afeb Chesa Arianto ${ }^{6}$, Ujang Nurdin ${ }^{7}$

$1,2,3,4,5,6,7$ Department of Sport Science, Yogyakarta State University, Yogyakarta Indonesia

ABSTRACT: This study aims to determine: (1) the relationship between the power of the arm muscles and the result of the gatein stroke, (2) the relationship between the length of the arm and the result of the gate-in stroke. (3) The relationship between hand eye coordination with the result of the gate-in stroke. (4) The relationship between concentration and the gate-in punch. (5) The relationship between arm muscle power, arm length, hand eye coordination, and concentration on the results of the gate-in stroke in woodball. This type of research is correlational. The population in this study were 54 athletes of Woodball in Bantul Regency, who were selected based on purposive sampling technique. The instruments used to measure the power of the arm muscles were the medicine ball test, the length of the arm with an anthropometer / meter, the concentration using the Grid Concentration Test, and the gate-in stroke with a modified gate-in punch density test. The data analysis technique used is multiple regression. The results showed that: (1) There was a significant relationship between arm muscle power and the gate-in punch, with $r$ count 0.845 , and $p<0.05$, and a contribution of $32.09 \%$. (2) There is a significant relationship between the length of the arm and the result of the gate-in blow, with $r$ count 0.585 , and $p<0.05$, and a contribution of $12.00 \%$. (3) There is a significant relationship between hand eye coordination and the results of the gate-in stroke, with $r$ count 0.855 , and $p<0.05$, and the contribution is $21.92 \%$. (4) There is a significant relationship between concentration and the results of the gate-in blow, with $r$ count 0.808 , and $p<0.05$, and a contribution of $21.39 \%$. (5) There is a significant relationship between arm muscle power, arm length, hand eye coordination, and concentration on the results of the gate-in stroke in woodball, with a calculated $F$ value of $84.798>\mathrm{F}$ table 2.56 , and $\mathrm{p}<0.05$, and a contribution of $87.40 \%$.

KEYWORDS: arm muscle power, arm length, hand eye coordination, concentration, gate-in

\section{INTRODUCTION}

Woodball is a new sport that is still foreign and rarely heard. Woodball is also a growing sport in the world. Woodball is an outdoor game that is played individually or in a team by hitting the ball gradually until it passes the ball into the net on each fairway (trajectory) with as few strokes as possible. Woodball was first developed in Taipei China, invented in 1990 by Mr. MingHui Weng and Mr. Kung Cu Young. Woodball is a modified sport of golf that considers elements of cost efficiency and environmental protection (Soetrisno, 2015: 10; Kriswantoro, 2015: 5). Woodball is a fun recreational sport.

Woddballis the target sport. The goal in the woodball game is to try to get the ball into a predetermined target with the least number of strokes possible, so that the winner in this woodball game is the athlete with the fewest number of strokes compared to other athletes. Woodball is a fairly simple sport, because in practice it only hits a ball that is always stationary (not moving). If the woodball athlete has mastered the basic movements, then the athlete can master the basic technique, the athlete can hit the ball effectively. The demands of hitting the ball in a woodball game are trying to hit the ball to make a small number of strokes to reach the target, so this game is difficult for beginners.

Dewi \& Broto (2019: 25) stated that basic technique is one of the foundations for someone to be able to play woodball by learning good and correct basic techniques that will make it easier for athletes to play woodball. Woodball basic techniques include techniques without tools and with tools. Techniques without tools include: swing motion, setup (preparation), preswing routines without tools. While the techniques with tools are preswing routines with mallets, long strokes, medium distance 


\section{Study of the Correlation between Arm Muscle Power, Arm Length, Hand-Eye Coordination, and Concentration on Gate-In Results in Woodball}

strokes, close range punches, and gating. Long stroke in woodball is one of the basic techniques that are important to master. Long strokes are taken when playing on a long-distance field.

It is important for a woodball athlete to master the basic techniques of woodball stroke, one of which is parking and gate-in. Parking or gate-in strikes can greatly determine success in completing a fairaway in the game, because these strokes are usually done to direct the ball directly into the gate or direct the ball so that it can easily enter the gate. The skill of playing woodball is adjusted to the needs. Classifying the skills that must be possessed by woodball athletes can be determined through the rules of the woodball game, the characteristics of the woodball game, and the biomotor abilities needed in the woodball game. The skill in question is how an athlete can find out why the ball shows a different character when moving, know how mallet tilt affects ball movement and control, and how to translate swing in distance and accuracy. Thus, to be a good woodball athlete, one must be able to control the ball from the mallet swing at different distances and angles.

Mastering good hitting techniques, of course, supported by good physical components. The physical component is the most important factor to achieve high abilities (Anderson, et al., 2015: 14; Kendzierski \& DeCarlo., 2016: 211). Elements in physical condition include muscle strength, speed, cardiovascular endurance, muscle endurance, balance, flexibility, explosive power, coordination (Donnelly et al., 2016: 1198). Doing a good shot in woodball is determined by several factors, one of which is arm muscle power. As revealed by Muhammad, et al. (2019) that "Specifically, grip and arm power contributes to long hit accuracy up to $45.18 \%$. Swing will determine the power and direction of mallet".

Mylsidayu (2015: 136) that power can be interpreted as "strength and speed that are carried out together in carrying out a motion. Bafirman \& Eahyuni (2019: 135) that in general according to the direction and form of movement, explosive power consists of acyclic explosive power and cyclic explosive power. Sports that require acyclic explosive power predominantly are throwing and jumping in athletics, elements of gymnastic movements, fencing and movements that require jumping (basketball, volleyball, pencak silat and so on). The need for power components can be determined from the aspect of the tools used and the basic techniques of woodball games. Based on the aspect of the tool used in the woodball game, the strength component is closely related to the body's ability to cope with the burden of the tool. The mallet is a bat used in woodball games made of wood in the shape of the letter "T" with a gross weight of about 800 grams. The length of the mallet is $90 \pm 10 \mathrm{~cm}$ which consists of a handle and a bottle-shaped head. Based on the specifications of the mallet used as a bat, it is known that the weight of the load that must be held by the body, especially in the upper extremity or upper limb, is about 800 grams. To be able to remain stable swinging a mallet with a load of about 800 grams during the game, it takes good upper extremity muscle strength and good back muscles. Based on the specifications of the mallet used as a bat, it is known that the weight of the load that must be held by the body, especially in the upper extremity or upper limb, is about 800 grams. To be able to remain stable swinging a mallet with a load of about 800 grams during the game, it takes good upper extremity muscle strength and good back muscles. Based on the specifications of the mallet used as a bat, it is known that the weight of the load that must be held by the body, especially in the upper extremity or upper limb, is about 800 grams. To be able to remain stable swinging a mallet with a load of about 800 grams during the game, it takes good upper extremity muscle strength and good back muscles.

Good or bad arm muscle power is also determined by the length of the arm. When viewed from an anatomical point of view, the length of the arm which consists of several bones does not produce power. As in Newton's second law, states that the longer the lever, the greater the force produced, and the less force is required. So the longer the arm, the more energy expended in making a shot (Maj'di, 2018: 1). The movement of the stroke is a swing movement of the arm that originates at the base of the arm to provide power when the arm hits the ball. Long arms will produce a longer range, so that it has an effect on hitting in woodball sports.

Good coordination is needed to be able to perform basic woodball hitting techniques, so as to be able to master the motion properly and correctly. In performing the basic technique of hitting woodball, an athlete must be able to string together movements from the prefix, swing, to follow-through stages. The movement must look harmonious, harmonious, and simultaneous, so that the movement will look flexible and not stiff. To be able to do this, woodball athletes must have good coordination skills. Imadudin (2020) the results of his research show that there is a relationship between arm muscle strength and hand eye coordination on long stroke skills in woodball sports.

Even though they already have a good hitting technique, sometimes a Woodball athlete cannot always enter the ball smoothly into the gate, because there are other determining factors that must be mastered by Woodball athletes, namely the mental factor. One of them is the level of concentration (Agustiar \& Sultoni, 2016). Woodball sports require a high level of concentration and composure, sometimes when an athlete is about to put the ball into the goal, he can be overwhelmed by feelings of doubt and fear, this is what often causes the failure of a Woodball athlete when making a shot. 


\section{Study of the Correlation between Arm Muscle Power, Arm Length, Hand-Eye Coordination, and Concentration on Gate-In Results in Woodball}

On the other hand, woodball athletes must also have the ability to make decisions, whether to hit the ball directly at the gate assuming the ball goes straight in or make another shot to adjust the distance and angle between the ball and the gate. Making a shot to adjust the distance and angle between the ball and the gate before gating is often called parking. Parking is usually done when the angle formed between the ball and the gate does not allow for direct gating even though the ball is close to the gate or the ball is too far from the gate area. This requires athletes to have skills in managing control and accuracy of strokes when parking and gating.

Based on the results of the researcher's observations when observing the Woodball Club in Bantul Regency in August 2020, most of the athletes made a gate-in stroke when the game was still not good. This is indicated by the wrong or inaccurate hitting direction, lack of concentration and fear when hitting, hitting the ball incorrectly in the middle of the rubber cross section, and the instability or unsteadiness of the mallet swing when making a shot. Athletes lack concentration when hitting, so the ball is not on target. The gate-in shot does not have enough power, so the ball moves slowly.

In woodball sports, swing is one of the most dominant techniques, therefore athletes who will swing or swing at the time of striking need good concentration and coordination. If an athlete cannot control the tension when he is about to hit, the muscles around his body become stiff, his concentration and coordination are disturbed, so that the results of the blow will not be optimal, so that it can damage the pattern of the next game.

Several related studies were carried out by Yazid, et al. (2016) showed that there was a significant relationship between concentration and long stroke results in the woodball sport. Furthermore, research by Yulianingsih, et al. (2020) shows that there is a relationship between emotional intelligence and the result of gatting woodball. Agustiar \& Sultoni (2016) research results show that there is a significant relationship between anxiety levels and gate-in hitting in woodball. Imadudin (2020) in his research results showed that there was a relationship between arm muscle strength and hand eye coordination on long stroke skills in woodball sports.

Based on the explanation of these observations, this study intends to further prove the "Correlation Study between Arm Muscle Power, Arm Length, Eye-Hand Coordination, and Concentration on Gate-In Hit Results in Woodball".

\section{METHODS}

This type of research is correlational. Correlational research is research conducted to determine whether there is a relationship and the amount of contribution between two or several variables (Arikunto, 2015: 247). The population in this study were Woodball athletes in Bantul Regency, totaling 74 athletes. Sampling in this study was done by purposive sampling. The criteria in determining this sample include: (1) not in a state of illness, (2) willing to be a research sample, (3) age 12-15 years, (4) still actively registered as an athlete in a club, and (5) minimum exercise duration 3 months. Variables are concepts that have varying values, have more than one value, state, category, or condition. A variable is something that is the main focus of researchers' attention, whose values vary and change (Budiwanto, 2017: 58). The independent variables in this study were arm muscle power, arm length, hand eye coordination, and concentration, while the result of the gate-in stroke was the dependent variable. The instrument used to measure arm muscle power is the medicine ball test, arm length withanthropometer/meter, concentration with Grid Concentration Test, and gate-in stroke with modified gate-in punch accuracy test/ Data analysis or data processing is an important step in research. In this study, data analysis used computer software tools in the form of SPSS (Statistical Product and Service Solutions) Version 23. SPSS is a computer program used to analyze data statistically. The data analysis techniques used in this research are requirements test, multiple linear regression analysis, hypothesis testing, and coefficient of determination analysis.

\section{RESEARCH RESULTS AND DISCUSSION}

The sample in this study was the Woodball Club in Bantul Regency which consisted of 3 clubs, namely Mustang Woodball Club, West Shinobi Woodball Club, and Imogiri Woodball Club, totaling 54 athletes. Statistical descriptions of arm muscle power, arm length, hand eye coordination, concentration, and gate-in strokes in woodball are as follows.

a. Data on arm muscle power of Woodball athletes in Bantul Regency obtained an average of $1.55 \mathrm{~cm}$, with a minimum value of $1.23 \mathrm{~cm}$ and a maximum value of 1.95 .

b. Data on the arm length of Woodball athletes in Bantul Regency obtained an average of $66.48 \mathrm{~cm}$, with a minimum value of $61.00 \mathrm{~cm}$ and a maximum value of $75.00 \mathrm{~cm}$.

c. Data on eye-hand coordination of Woodball athletes in Bantul Regency obtained an average of 11.26 times, with a minimum score of 5 times and a maximum value of 19 times. 
Study of the Correlation between Arm Muscle Power, Arm Length, Hand-Eye Coordination, and Concentration on Gate-In Results in Woodball

d. Data on the concentration of Woodball athletes in Bantul Regency obtained an average of 13.65, with a minimum value of 6.00 and a maximum value of 22.00 .

e. The gate-in data for Woodball athletes in Bantul Regency is obtained an average of 15.65, with a minimum score of 9.00 and a maximum value of 26.00 .

\section{Multiple Linear Regression Equation}

Multiple regression analysis was used to test the independent variables together with the dependent variable. The results of multiple linear analysis of arm muscle power, arm length, hand eye coordination, and concentration on the results of the gate-in stroke in woodball:

$$
Y=18.965+7.510 \times 1+0.230 \times 2+0.314 \times 3+0.302 \times 4
$$

Test Analysis Results (Simultaneous)

$F$ test is a means of testing to determine whether the independent variables simultaneously (simultaneously) affect the dependent variable. The results of the analysis are in Table 1.

Table 1. F Test Analysis Results (Simultaneous)

\begin{tabular}{|c|c|c|c|c|c|c|}
\hline \multicolumn{7}{|c|}{ ANOVAb } \\
\hline \multicolumn{2}{|c|}{ Model } & Sum of Squares & $d f$ & Mean Square & $F$ & Sig. \\
\hline \multirow[t]{3}{*}{1} & Regression & 720,264 & 4 & 180,066 & 84,798 & $.000 a$ \\
\hline & Residual & 104,050 & 49 & 2,123 & & \\
\hline & Total & 824,315 & 53 & & & \\
\hline \multicolumn{7}{|c|}{ a. Predictors: (Constant), Concentration, Arm Length, Arm Muscle Power, Hand Eye Coordination } \\
\hline \multicolumn{7}{|c|}{ b. Dependent Variable: Gate In } \\
\hline
\end{tabular}

Based on Table 8 above, the calculated F coefficient is $84,798>\mathrm{F}$ table 2.56 , the value of sig. $0.000<0.05$ then Ho is rejected, meaning. The alternative hypothesis which reads "There is a significant relationship between arm muscle power, arm length, hand eye coordination, and concentration on the results of the gate-in stroke in woodball sports", was accepted.

\section{T-Test Analysis Results (Partial)}

1) The relationship between arm muscle power and the result of the gate-in

The proposed hypothesis reads "There is a significant relationship between arm muscle power and the results of the gate-in stroke in woodball sports". The results of the analysis are presented in Table 2 as follows.

Table 2. Correlation between Arm Muscle Power and Gate-In Stroke Results

\begin{tabular}{|l|l|l|l|l|}
\hline Connection & r count & t count & Significance & Description \\
\hline $\mathrm{X} 1 . \mathrm{Y}$ & 0.845 & 4,157 & 0.000 & Significant \\
\hline
\end{tabular}

Based on the results of the analysis, showing the arm muscle power variable, the $r$-count value was 0.845 , the $t$-count was 4.157 and the significance value (sig) was 0.000 . Because the significance value is $0.000<0.05$, then $\mathrm{HO}$ is rejected, meaning that $\mathrm{Ha}$ which reads "There is a significant relationship between arm muscle power and the result of hitting the gate-in in woodball sports" is accepted. The correlation coefficient is positive, meaning that if the arm muscle power gets better, then the gate-in results in woodball sports will also get better.

2) The relationship between arm length and the result of the gate-in

The proposed hypothesis reads "There is a significant relationship between arm length and the result of the gate-in stroke in woodball sports". The results of the analysis are presented in Table 3 as follows.

Table 3. Correlation between Arm Length and Gate-In Stroke Results

\begin{tabular}{|l|l|l|l|l|}
\hline Connection & r count & t count & Significance & Description \\
\hline X2.Y & 0.585 & 3,509 & 0.001 & Significant \\
\hline
\end{tabular}

Based on the results of the analysis, it shows that the arm length variable has an $r$-count value of 0.585 , a t-count of 3.509 and a significance value (sig) of 0.000 . Because the significance value is $0.001<0.05$, then $\mathrm{HO}$ is rejected, meaning that Ha which reads 


\section{Study of the Correlation between Arm Muscle Power, Arm Length, Hand-Eye Coordination, and Concentration on Gate-In Results in Woodball}

"There is a significant relationship between arm length and the result of hitting the gate-in in woodball sports" is accepted. The correlation coefficient is positive, meaning that if the arm length is getting better, then the gate-in shot in woodball will also be better.

3) The relationship between eye-hand coordination and the result of the gate-in

The proposed hypothesis reads "There is a significant relationship between hand eye coordination and the results of the gate-in stroke in woodball sports". The results of the analysis are presented in Table 4 as follows.

Table 4. Correlation between Eye-Hand Coordination with Gate-In . Strike Results

\begin{tabular}{|l|l|l|l|l|}
\hline Connection & r count & t count & Significance & Description \\
\hline X3.Y & 0.855 & 2,479 & 0.017 & Significant \\
\hline
\end{tabular}

Based on the results of the analysis, showing the eye-hand coordination variable, the $r$-count value was 0.855 , the $t$-count was 2.479 and the significance value (sig) was 0.017 . Because the significance value is $0.017<0.05$, then $\mathrm{H} 0$ is rejected, meaning that Ha which reads "There is a significant relationship between eye-hand coordination and the result of hitting the gate-in in woodball sports" is accepted. The correlation coefficient is positive, meaning that if the eye-hand coordination is getting better, then the gate-in results in woodball sports will also be better.

4) The relationship between concentration and the result of the gate-in pukulan

The proposed hypothesis reads "There is a significant relationship between concentration and the result of hitting the gate-in in woodball sports". The results of the analysis are presented in Table 5 as follows.

Table 5. Correlation between Concentration and Gate-In Hit Results

\begin{tabular}{|l|l|l|l|l|}
\hline Connection & r count & t count & Significance & Description \\
\hline X4.Y & 0.808 & 3,292 & 0.002 & Significant \\
\hline
\end{tabular}

Based on the results of the analysis, showing the concentration variable, the $r$-count value is 0.808 , the t-count is 3.292 and the significance value (sig) is 0.002 . Because the significance value is $0.002<0.05$, then $\mathrm{HO}$ is rejected, meaning that Ha which reads "There is a significant relationship between concentration and the result of hitting the gate-in in woodball sports" is accepted. The correlation coefficient is positive, meaning that the better the concentration, the better the gate-in results in woodball.

Coefficient of Determination (R2)

The coefficient of determination (R2) is essentially used to measure how far the regression model's ability to explain the variation of the dependent variable is. The results of the analysis in Table 6 are as follows:

Table 6. Results of the Analysis of the Coefficient of Determination (R2)

\begin{tabular}{|l|l|l|l|l|}
\hline \multicolumn{4}{|l|}{ Model Summary } \\
\hline Model & $\boldsymbol{R}$ & $\boldsymbol{R}$ Square & Adjusted $\boldsymbol{R}$ Square & Std. Error of the Estimate \\
\hline 1 & $.935 \mathrm{a}$ & .874 & .863 & 1.45722 \\
\hline \multicolumn{2}{|l|}{ a. Predictors: (Constant), Concentration, Arm Length, Arm Muscle Power, Hand Eye Coordination } \\
\hline
\end{tabular}

The table above shows that the value of $\mathrm{R}$ Square is 0.874 or $87.4 \%$. This means that the independent variables of arm muscle power, arm length, hand eye coordination, and concentration together affect the dependent variable on the outcome of the gate-in stroke in woodball by $\mathbf{8 7 . 4 \%}$ while the remaining $12.60 \%$ is influenced by other variables. not included in this study, for example talent, practice, and technique.

\section{DISCUSSION}

\section{The Relationship between Arm Muscle Power and Gate-In Hit Results}

Based on the results of the study showed that there was a significant relationship between arm muscle power and the results of the gate-in stroke in woodball sports. The magnitude of the contribution of arm muscle power with the result of the gate-in hit is $32.09 \%$. The results of this study confirm that the relationship between the two variables is positive, meaning that the stronger the arm muscle power, the better the gate-in results. Arm muscle explosive power is a physical condition that cannot be 


\section{Study of the Correlation between Arm Muscle Power, Arm Length, Hand-Eye Coordination, and Concentration on Gate-In Results in Woodball}

separated and is the main support for movement, namely muscle strength and muscle speed to direct maximum power. Arm muscle explosive power is a very important factor and must be considered in woodball sports, especially when hitting, so having good arm muscle explosive power will produce a better gate-in shot.

Explosive power (muscular power) is a person's ability to use his strength to the fullest in the shortest possible time. With this, it can be stated if the explosive power (power) is equal to the speed (felocity) x strength (force) (Kraemer \& Looney, 2016: 14). Power is a combination of speed and strength or direction of maximum muscle force with maximum speed. Fast and strong abilities are also needed by athletes to make fast movements and need strong power (Rahmansyah, et al., 2018: 40; Sunardi, et al., 2019: 1).

Verma (2014) in his research revealed that power helps players maintain corners. The special relationship between muscle power and exercise technique is seen in daily movements performed with the dominant and non-dominant extremities. Analysis performed during the movement with the weaker arm, compared to the same movement using the dominant arm, showed not only a decrease in exercise efficiency, but also a change in the regression law (Peric, et al. 2015).

The accuracy of the gate-in stroke, it takes a good explosive power of the arm muscles, it is hoped that the development of achievement from an early age through well-programmed exercises. Explosive power training in doing gate-in punches requires a lot of muscle cooperation in coordinating and providing acceleration so that the transfer of energy impulses occurs very quickly between muscles. By doing regular exercise, muscles will become strength, develop and make the body's organs function properly (Gatta, et al., 2015: 23). Doing regular exercise, muscles will become strong, develop and make the function of body organs better (Aditama, 2020). Sung et al (2016) stated that a combination of core and non-dominant arm strength training can provide a more effective specific training program than core training alone for golfers to increase distance.

\section{Relationship between Arm Length and Gate-In Strike Results}

Based on the results of the study, it showed that there was a significant relationship between arm length and the results of the gate-in stroke in woodball. The amount of the contribution of the length of the arm with the result of the gate-in hit is $12.00 \%$. The results of this study confirm that the relationship between the two variables is positive, meaning that the longer the arm, the better the gate-in result. These results are in line with research conducted by Faizin \& Hariadi (2019) that there is a significant relationship between arm length and throw-in, which is obtained by $r$ count of 0.67 , thus the interpretation of the relationship is in the medium category and the relationship shows a positive direction of relationship.

The arm is one of the upper limbs or upper extremities in the human body that functions to carry out movements such as lifting, pushing, pulling, hitting, rejecting, and throwing. Arm length is the distance from the upper arm bone (humerus) to the ulna (Syarifudin, 2016: 2). Sleeve length is the length of the hand from the ochromeon to the wrist. The arm is included in the extremity joints in the human body. The arm has three parts of the muscles that support the arm including the shoulder muscles, the base of the upper arm muscles, and the forearm muscles. The muscles in the arms are located in the upper extremities of the human body, divided into the upper and lower arms (Syaifudin, 2016: 143).

Hermayani, et al (2018: 62) states that arm length is the distance from the upper arm bone (humerus) to the ulna. An object moving at the long end of the radius will be linearly larger than an object moving at the short end if the angular velocity is kept constant. The arm-length swing motion is an angular motion that occurs when an object moves in a circular path around a fixed point. This means that the distance traveled can be in the form of a small arc/a full circle that rotates at the joint, in th is case the shoulder joint. Furthermore, it is explained that the skeleton of the body is composed of a system of levers. The lever of a rigid rod moves in a circular arc around its axis, so the motion is called angular motion.

Margono (2017: 6) argues that the greater the strength possessed by the arm length, the more functions, advantages and uses it has in sports. People who have long arms if they have good physical, technical, mental elements, it is believed that their performance will be better, and long arms are part of the body that gives advantages for sports that require far throws or punches.

\section{Relationship between Eye-Hand Coordination with Gate-In Strike Results}

Based on the results of the study, it shows that there is a significant relationship between hand eye coordination and the results of the gate-in stroke in woodball sports. The contribution of eye-hand coordination with the result of the gate-in hit is $21.92 \%$. The results of this study confirm that the relationship between the two variables is positive, meaning that the better the eyehand coordination, the better the gate-in results. This is in line with research which shows that the contribution of eye-hand coordination to service accuracy only contributes $25.3 \%$ (Andria \& Igorosky, 2020). The accuracy of hitting and the success of athletes in the future can be seen from the high level of eye-hand coordination of athletes today (Laby, et al., 2018). Akbari, et al. (2017) stated "Eye-hand coordination directly effects badminton smash skills by 8.64\%". Yulianti (2017) added that hand-eye 


\section{Study of the Correlation between Arm Muscle Power, Arm Length, Hand-Eye Coordination, and Concentration on Gate-In Results in Woodball}

coordination contributed $20.79 \%$ to smash accuracy. Setianingrum et al. (2018) that the contribution of hand-eye coordination of $14.3 \%$ to accuracy. Purnomo \& Yendrizal (2019) in their research showed that eye-hand coordination contributed $74.13 \%$ to the accuracy of the stroke.

A study explained that the speed of eye-hand coordination could not be done perfectly if the athlete had an injury to the neck, without eye movements assisted by agile neck rotation, good eye-hand coordination could not be obtained, so athletes would also have difficulty serving (Mutasim, 2007). et al., 2020; Przednowek, et al., 2019). Rahmadiky (2020) shows that hand eye coordination is closely related to service accuracy.

Irianto (2018: 77 ) states that coordination is the ability to perform movements at various levels of difficulty quickly and precisely efficiently. The level of good or bad coordination of a person's movements is reflected in his ability to perform a movement skillfully. An athlete with good coordination is not only able to perform a skill perfectly, but also easily and quickly in performing a skill that is still new to him. Coordination is the ability to perform movements with varying degrees of difficulty quickly and efficiently and with full accuracy. Good coordination will be able to carry out various movements with various levels of difficulty quickly, fully targeted and of course efficient in their movements (Syafutra, 2020: 203).

Coordination is needed in almost all sports competitions and games, coordination is also important when in unfamiliar situations and environments, for example changes in the playing field, equipment, weather, lighting, and the opponents they face. The level of good and bad coordination of a person's movements is reflected in the ability to perform a movement smoothly, precisely, quickly, and efficiently. Coordination ability allows athletes to perform a group of movements with better quality of movement. Coordinative ability is needed for maximum utilization of conditional abilities, technical skills (Gogoi \& Pant, 2017: 53). Throwing, hitting, pushing, or pulling skills require hand eye coordination. Eye-hand coordination combines the ability to see and the ability of the hand, for example in the game of table tennis before the movement hits the eye must lead to the target or the intended object. Eye-hand coordination will result in timing and accuracy. Timming is oriented to timeliness, accuracy is to target accuracy. Through good timing, the contact between the hand and the object will be in accordance with the wishes so that it will produce an effective movement. Accuracy will determine whether the object is right for the intended target. The contact between the hand and the object will be in accordance with the wishes so that it will produce an effective movement. Accuracy will determine whether the object is right for the intended target. The contact between the hand and the object will be in accordance with the wishes so that it will produce an effective movement. Accuracy will determine whether the object is right for the intended target.

\section{Relationship between Concentration and Gate-In Hit Results}

Based on the results of the study, it was shown that there was a significant relationship between concentration and the result of hitting the gate-in in woodball. The contribution of concentration with the result of the gate-in hit is $21.39 \%$. The results of this study confirm that the relationship between the two variables is positive, meaning that the better the concentration, the better the gate-in results. These results are in line with the research of Irawan, et al. (2019) that there is a relationship between concentration and coordination in shooting accuracy on the learning achievement of petanque athletes. Haryanto \& Amra (2020) added that "Concentration and hand eye coordination together have a strong enough relationship with backhand backspin service accuracy". Purnomo \& Yendrizal (2019) in their research showed that concentration contributed 5,

Concentration is the athlete's ability to maintain the focus of his attention on the relevant game environment. Concentration is the athlete's ability to focus his attention on a selected stimulus (one object) in a certain period of time. Furthermore, concentration is the ability to focus on various factors relevant to the match and be able to maintain it for the duration of the match (Tangkudung, 2018: 391). Concentration is a component of cognitive function, which is important for athletes in any sport. Each sport has its own characteristics, body contact or non-body contact, based on aspects of game activities that have direct or indirect physical contact, sports rules, athlete behavior, and psychological demands.

A person's ability to focus or concentrate on certain incoming cues in accordance with his task will provide optimal results for his task. From psychological factors, one of them is that high concentration is needed because every movement made will determine the accuracy of the stroke. There are three barriers that hinder the athlete's concentration during the competition so that it interferes, namely staying silent on the initial mistakes, too focused on the results of the competition and too focused on the body and mechanical movements (Setiawan, et. al. 2018). Concentration disturbed by noise made by spectators should not be used as an excuse by professional players. Because these concentrations are so high which is important,

Without good concentration, athletes can make various mistakes in their performance such as failing to display the techniques that have been learned, lack of accurate sports movements that should be done, or in archery can also mean the athlete's failure to shoot targets with high points (Indahwati \& Ristanto, 2016: 132; Jannah, 2017: 49). In important situations, a momentary loss 


\section{Study of the Correlation between Arm Muscle Power, Arm Length, Hand-Eye Coordination, and Concentration on Gate-In Results in Woodball}

of concentration can affect performances and affect the outcome of the match. This is because the focus of attention significantly affects appearance (Zahedi, et al., 2011: 2).

\section{The Relationship between Arm Muscle Power, Arm Length, Hand Eye Coordination, and Concentration on Gate-In Hit Results}

Based on the results of the study, it was shown that there was a significant relationship between arm muscle power, arm length, hand eye coordination, and concentration on the results of the gate-in stroke in woodball. The magnitude of the contribution of arm muscle power, arm length, hand eye coordination, and concentration with a gate-in hit was $87.40 \%$. Of the several independent variables in this study, the arm length variable is the variable that gives the smallest contribution compared to the arm muscle power, hand eye coordination, and concentration variables to the gate-in stroke result.

Therefore, how the role of concentration when the athlete hits must be known, as well as the contribution of eye-hand coordination which plays a very important role in hitting the athlete and must also be known by the athlete and the coach himself, this is useful for considering the development of a training program., so that the accuracy service becomes more accurate and consistent (Mutasim, et al., 2020; Przednowek, et al., 2019). The results of this study are in line with the research of Imanudin (2020) that there is a relationship between arm muscle strength and hand eye coordination on long stroke skills in woodball sports.

If a player already has good eye-hand coordination, good hitting practice is one way. The target of hitting varies, in contrast to athletes who have not been trained in hand-eye coordination, then the direction of the blow must be corrected first. With the trainer's attention regarding the suitability of the form of training. According to the player's level of coordination, the player's accuracy ability will develop rapidly (Andria \& Igorosky, 2020; Basiri, et al., 2020).

\section{CONCLUSIONS}

Based on the results of the research and the results of the data analysis that has been carried out, the following conclusions are obtained.

1. There is a significant relationship between arm muscle power and the results of the gate-in in woodball, with a contribution of $32.09 \%$.

2. There is a significant relationship between arm length and the result of the gate-in stroke in woodball, with a contribution of $12.00 \%$.

3. There is a significant relationship between hand eye coordination and the result of hitting the gate-in in woodball, with a contribution of $21.92 \%$.

4. There is a significant relationship between concentration and the result of hitting the gate-in in woodball, with a contribution of $21.39 \%$.

5. There is a significant relationship between arm muscle power, arm length, hand eye coordination, and concentration on the results of the gate-in stroke in woodball, with a contribution of $87.40 \%$.

\section{REFERENCES}

1) Abdurrahman, M., \& Setiadi, F (2019). The relationship between arm muscle strength, eye-hand coordination on the ability of passing down extracurricular students of MTS Negeri 1 Sukabumi. Indonesia Sport Journal, 2(2).

2) Aditama, F., Sugiharto, \& Kusuma, DWY (2020). The correlation of arm muscle strength, grip strength, and body flexibility to the results of long-distance shots on woodball. Journal of Physical Education and Sports, 9(1), 69-75.

3) Ahwadi, L., Yudiana, Y., \& Kusmaedi, N. (2016). The relationship between eye and hand coordination with the catch of the infield, outfield ball in the softball sport. Journal of Applied Sports Science, 1(2).

4) Akbari, M., Dlis, M., \& Widiastuti. (2017). The effect at muscle power arm, hand-eye coordination, flexibility and self confidence upon badminton smash skill. Journal of Indonesian Physical Education and Sport, 3(2), 84-94.

5) Andria, Y., \& Igorosky, A. (2020). The contribution of grip strength and eye-hand coordination towards service accuracy in tennis athletes. Jipes-Journal of Indonesian Physical Education and Sport, 6(01), 17-22.

6) Asnaldi, Arie, Nirwandi, N., \& Aprisandy, D. (2019). The effect of weight training on increasing arm muscle explosive power. Sports Science, 19(1), 1-9.

7) Bastug, G. (2018). Investigation of attention, concentration and mental toughness properties in tennis, table tennis, and badminton athletes. The Sports Journal, 21. 


\section{Study of the Correlation between Arm Muscle Power, Arm Length, Hand-Eye Coordination, and Concentration on Gate-In Results in Woodball}

8) Belkebiche, K., Ahmed, A., \& Djamel, M. (2016). Some aspects of attention and skill relationship, accuracy correction of the basketball players middle class. European Journal of Education Studies, 8(2).

9) Budiman, AF, \& Widiyanto. (2014). The difference in the angle of repulsion to the value of leg power. Medikora, XIII(1).

10) Budiwibowo, F., \& Setiowati, A. (2015). Elements of body mass index and leg muscle strength in balance. Journal of Sport Sciences and Fitness, 4(2).

11) Chen, L., Zhang, H., \& Meng, L. (2018). Study on the influence of plyometric training on the explosive power of basketball players. International Journal of Physical Education, Sports and Health; 5(3), 140-143.

12) Faizin, A., \& Hariadi, I. (2019). The relationship between arm length and arm muscle strength against throw-in in students. Indonesia Performance Journal, 3(2).

13) Hambali, S., \& Sobarna, A. (2019). Correlation study between arm power, hand eye coordination and self-confidence in Osas club athletes, Sumedang Regency. Olympia Journal, 1 (2).

14) Haqiyah, A., Mulyana, Widiastuti, \& Riyadi, DN (2017). The effect of intelligence, leg muscle strength, and balance towards the learning outcomes of pencak silat empty handed single artistic. Journal of Education, Teaching and Learning, 2(2), 211-217.

15) Imaduddin, MF (2020). The relationship between arm muscle strength and hand eye coordination on mastery of long stroke technique in woodball, JPOS (Journal Power of Sports), 3(2), 37-41.

16) Komarudin, \& Mulyana. (2017). The effect of brain jogging exercise toward the increase of concentration and learning achievement. Paper presented at the IOP Conference Series: Materials Science and Engineering.

17) Kriswantoro \& Anas, KA (2012). Basic techniques of playing woodball. Semarang: IWbA.

18) Lu, Y., \& Luo, Y. (2014). Woodball mallet loading analysis during maximal swing stage: A finite element study. Journal of Chemical and Pharmaceutical Research, 6(6), 756-759.

19) Mahendra, IR, Nugroho, P., \& Junaidi, S. (2012). Wrist flexibility and hand eye coordination on the ability to hit table tennis forehands. Journal of Sport Sciences and Fitness, 1(1).

20) Oktaria, R., Sinurat, R., \& Janiarli, M. (2020). The relationship between arm muscle strength and arm length with the ability to throw discs in class XI IPS 1 SMA N 1 Rambah. Sport Education and Health Journal, 1(1), 1-8.

21) Purnomo, A., \& Yendrizal. (2019). Effect of hand-eye coordination, concentration and believe in the accuracy of shooting in petanque. Advances in Social Science, Education and Humanities Research, 460.

22) Putu, CPD, \& Sukadiyanto. (2015). Woodball sports skill test development for beginners. Journal of Sport, 3(2), 228-240.

23) Reddy, A., Arunachalam, R., \& Anitha, A. (2017). Correlation between core muscle strength and hand-eye coordination in non athletes. Int J Physiother, 4(5), 291-295.

24) Reid, KF, \& Fielding, RA (2012). Skeletal muscle power: A critical determinant of physical functioning in older adults. Exercise and Sport Sciences Reviews, 40, 4-12.

25) Retnowulan, RRB, Sugiyanto, \& Purnama, SK (2017). The contribution of body height, arm length, arm muscle strength and leg power on the ability of free throw shoot of woman basketball athletes. European Journal of Physical Education and Sport Science, 3(3).

26) Sangap, A., Barata, I., \& Apriyanto, T. (2019). The relationship between arm muscle power and eye-hand coordination with rugby passing accuracy, State University of Jakarta. Scientific Journal of Sport Coaching and Education, 3.

27) Septianingrum, K., Sugiyanto, Kristiyanto, A., Hudayhana, NL, \& Putra, DPY (2018). Physical condition as a contribution of shooting accuracy with flick drag technique. Journal of Physical Education, Sport, Health and Recreations, 7(2), 58-62.

28) Singh, K., \& Singh, R. (2015). Relationship of selected anthropometric variables with the throwing distance of cricket ball in cricket. Academic Sports Scholars, 4(8), 1-6.

29) Sobarna, A., \& Friskawati, GF (2018). Student Situational Interest after Following Outdoor Education. In Malaysian International Outdoor Recreation and Education Conference 2018.

30) Syafutra, W. (2020). The relationship between eye-hand coordination and shooting results for SME basketball athletes from STKIP PGRI Lubuklinggau. Edumaspul Journal, 4(1), 202-207.

31) Tache, N., Lubis, L., \& Saputra, L. (2017). Concentration level differences between athletes of body contact and non-body contact sports. Althea Medical Journal, 4(3), 396-401.

32) Utama, RR, Hasyim, AH, \& Asri, A. (2020). The relationship between arm muscle strength and arm length on smash ability in volleyball games for class XI students of SMK Negeri 10 Makassar. Sports Review Journal, 1(1).

33) Wagh, PD, Birajdar, G., \& Nagavekar, M. (2017). Comparison of handgrip muscle strength in sportsmen and sedentary group. IOSR Journal of Dental and Medical Sciences, 16(7), 62-65. 
Study of the Correlation between Arm Muscle Power, Arm Length, Hand-Eye Coordination, and Concentration on Gate-In Results in Woodball

34) Widodo, W., \& Hafidz, A. (2018). The contribution of arm length, hand eye coordination, and concentration to shooting accuracy in petanque sports. Journal of Sports Achievement, 3(1).

35) Yazid, S., Kusmaedi, N., \& Pramitha, ST (2016). The relationship between concentration and the results of long strokes in woodball. Journal of Applied Sports Science, 1(1).

There is an Open Access article, distributed under the term of the Creative Commons Attribution - Non Commercial 4.0 International (CC BY-NC 4.0)

(https://creativecommons.org/licenses/by-nc/4.0/), which permits remixing, adapting and building upon the work for non-commercial use, provided the original work is properly cited. 